\title{
Article
}

\section{Challenges to the European automotive industry in securing critical raw materials for electric mobility: the case of rare earths}

\author{
Marc Schmid* \\ Martin-Luther-Universität Halle-Wittenberg, Department of Economics, Große Steinstraße 73, 06108 Halle (Saale), Germany
}

\begin{abstract}
Critical raw materials (CRMs) are crucial for the transformation towards low carbon mobility. However, their production is often highly concentrated in a few countries, which leads to supply risks. Exemplified by the case of rare earth elements (REEs) and based on in-depth interviews with corporate executives from companies along the automotive supply chain, this contribution provides insights into the strategies of the European automotive industry to cope with these supply risks. Results show a lack of awareness of $R E E$ criticality studies and their outcomes in the past, the decisive role of price competitiveness when pursuing mitigation strategies and a lack of willingness or ability to engage in rare earth (RE) projects to get access to production output and secure supply. Overall, affected companies struggle to pursue long-term oriented strategies to secure their need for REEs. These findings are discussed with regard to the new demand for CRMs due to the shift to electric mobility and the specific challenges that the automotive industry faces.
\end{abstract}

Keywords: rare earths, critical metals, criticality, mitigation strategies, electric vehicles, automotive industry

(Received 26 August 2019; accepted 7 February 2020; Accepted Manuscript published online: 24 February 2020; Associate Editor: Eimear Deady)

\section{Introduction}

The shift from automotives with internal combustion engines (ICE) to electric vehicles (EVs) is considered to be one of the most fundamental transformations the automotive industry has faced in decades (Tran et al., 2012; Hardman et al., 2013). EVs require innovative technologies and some new raw materials not used in the former ICE cars.

Europe is especially affected by this development. The European automotive industry is among the most important industries of the EU's economic powerhouse. The 12 million employees of the automotive industry account for $\sim 4 \%$ of the EU's GDP and an export volume of passenger cars worth $€ 128$ billion (ACEA, 2019). Europe is home to some of the biggest car manufacturers (OEMs - original equipment manufacturers) such as Volkswagen, Daimler and BMW in Germany, PSA and Renault in France, and Fiat Chrysler Automobiles (FCA) in Italy and the Netherlands, as well as world leading automotive suppliers like Bosch, Continental, ZF Friedrichshafen and Mahle in Germany; Michelin, Faurecia, and Valeo in France; Magneti Marelli in Italy; and a substantial supply industry in Great Britain. Adoption rates of electric vehicles have increased considerably in recent years. Dijk et al. (2013) stated in 2013 that electric mobility (e-mobility) has crossed a critical threshold as it benefits from high oil prices, carbon emission constraints and the rise of car sharing and intermodality. The adoption of

\footnotetext{
*Author for correspondence: Marc Schmid, Email: marc.schmid@wiwi.uni-halle.de This paper is part of a thematic set arising from the 3rd International Critical Metals Conference (Edinburgh, May 2019).

Cite this article: Schmid M. (2020) Challenges to the European automotive industry in securing critical raw materials for electric mobility: the case of rare earths. Mineralogical Magazine 84, 5-17. https://doi.org/10.1180/mgm.2020.9

EVs is further driven by the political and societal will to decarbonise the World economy (White and Sintov, 2017; Kester et al., 2018). The market for electric vehicles is becoming more significant with regard to sales volume and overall market size. The global development of the market for electric vehicles is illustrated in Fig. 1.

Worldwide, about 2.1 million EVs were sold in 2018 and total EVs in stock has surpassed 5 million units, which is a strong increase in comparison to 3.1 million units a year ago (IEA, 2018, 2019). Annual sales in 2018 therefore almost doubled in comparison to 2017. Although these numbers tend to appear small in comparison to total annual sales of passenger cars, which amounted to 79 million units in recent years (ACEA, 2018a), EV market growth is accelerating.

The current development is leading to a shift away from a niche market, and EVs are considered the future by governments as well as companies (Altenburg et al., 2015; Ewing, 2017; Styczynski and Hughes, 2019). As of 2018, most car manufacturers have already started production of EVs or are on their way in doing so (Stock, 2018). Whereas some automobile manufacturers see themselves as pioneers who had introduced their first EVs years ago (BMW, 2017a), others can be seen as incumbents that now invest heavily in EVs: Volkswagen, the biggest carmaker worldwide, announced 70 new electric models for the upcoming years (Volkswagen, 2019). General Motors stated that it would prepare its portfolio for an all-electric future (GM, 2019). The Ford Motor Company plans to invest US-\$ 11 billion and to have a line-up of 40 electrified vehicles by 2022 (Carey and White, 2018). Similar announcements were made by all other major car companies.

Increased production rates of EVs will also lead to new material demand as the replacement of ICE by EVs will substitute 


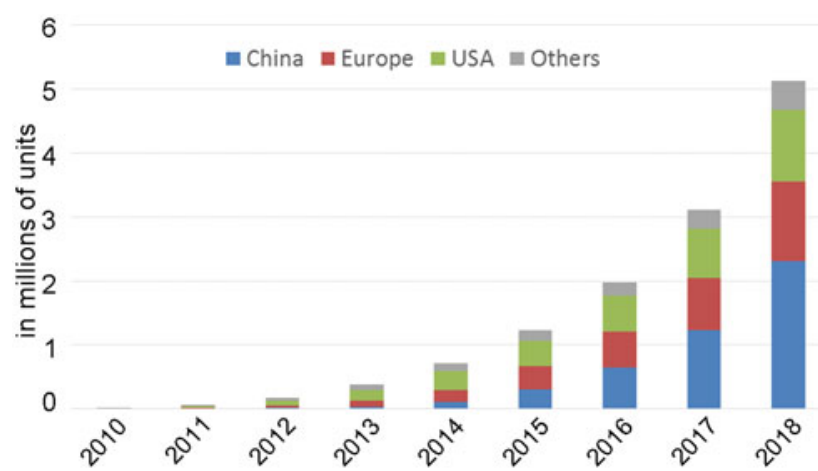

Fig. 1. Development of electric vehicles in stock (illustration based on data by IEA 2017, 2018, 2019).

energy raw materials for mineral raw materials (Vidal et al., 2013; de Koning et al., 2018). So-called critical raw materials (CRMs), especially, are an important success factor and potential bottleneck in the transformation process (Ziemann et al., 2013; Olivetti et al., 2017; Ortego et al., 2018). Raw materials are considered critical according to their relevance and existing supply risks (Graedel et al., 2012). Different scholars have recently stressed the importance of CRMs for the automotive industry in the transformation process to an all-electric future (Grandell et al., 2016; Jussani et al., 2017; Pavel et al., 2017). Several automotive manufacturers have also raised the alarm. The market leader in the EV business, Tesla, currently sees supply risks for minerals required for EVs and warned of underinvestment in the mining industry (Scheyder, 2019). In 2017, the world's biggest car manufacturer Volkswagen could not place a contract to secure its need for cobalt for its EVs in the upcoming years. Talks with the cobalt industry ended without results (Desai, 2017). Sergio Marchionne, the former CEO of Fiat Chrysler Automobiles (FCA), has stressed: "[...] in an ever-changing world, the interconnected nature of supply chains puts them at risk for disruption from fluctuating demand, shortages of key commodities, geopolitical dynamics, natural disasters and other events that are difficult to predict" (Marchionne, 2013).

Given the background described above, this paper analyses the markets for CRMs that are required for EVs, and addresses the following research questions on the basis of the rare earths (RE) case study:

What are the specific characteristics of the markets for REEs?

How do affected companies try to address them?

What are the specific challenges for companies when

responding to the existing supply risks?

A detailed look into the black box of corporate strategies in the European automotive industry provides insights into strategies to secure the RE supply and associated challenges. This paper concludes with a discussion of the lessons learned for the future of CRMs for EVs in general.

\section{Critical raw materials for the EV revolution}

\section{The most critical raw materials}

EVs are based on two major components: drivetrain and battery. Although there are various alternative batteries such as nickelmetal hydride $(\mathrm{NiMH})$, lead-acid and vanadium redox flow batteries and alternative technologies like fuel cells (Cano et al., 2018), lithium-ion batteries (LIB) have become the dominant technology (Nykvist and Nilsson, 2015). Most LIBs are either lithium nickel manganese cobalt oxide (NMC), lithium nickel cobalt aluminium oxide (NCA) or lithium manganese dioxide (LMD) batteries. Depending on the chemistry and battery type, amounts of the CRMs that are required vary. In general, cobalt, lithium, graphite, nickel and manganese are employed. In recent years, nickel-metal hydride (NiMH) batteries have been used in hybrid electric vehicles (HEVs), which contain REEs (Pollet et al., 2012).

Critical raw materials also play a crucial role in the drivetrain. Electric vehicles are usually powered by permanent magnet (PM)based synchronous drives that require neodymium-iron-boron $(\mathrm{NdFeB})$ magnets, which contain REEs. Although there are various alternatives to RE-based electric drives, for example, asynchronous drives, electric drives that rely on $\mathrm{NdFeB}$ magnets have high performance and are especially energy efficient. Consequently, market share of PM drives accounts for an estimated $90 \%$ of all battery electric vehicle models on the market (Roskill, 2018). Among the EVs that use PM drives are many top selling cars from practically all major car manufacturers in the EV market, such as the BMW i3, BYD e6, Citroen C-Zero, Chevrolet Volt, Honda Insight, Hyundai Kona Electric, Mitsubishi i-MiEV, Nissan Leaf and Toyota Prius (Boldea et al., 2014; Erdmann et al., 2015; Widmer et al., 2015; Hyundai, 2018; Evans, 2019). Their superior performance also led to a shift by Tesla, the world's biggest electric car company, to $\mathrm{NdFeB}$ magnet-based drives for its high performance models (Desai, 2018). NdFeB permanent magnet-based drive technology is also used in HEVs, as space and weight are particularly critical factors in the hybrid systems. NdFeB magnets contain the REEs neodymium, dysprosium and terbium. Although current sales numbers are relatively small, with 2 million EVs sold worldwide in 2018, it is expected that global passenger EV sales will reach 28 million in 2030 and 56 million in 2040 (BloombergNEF, 2019). CRMs for EVs may therefore become a much bigger issue in the upcoming decades.

An overview of the raw material basis of EVs and the respective market structure of the production of rare earths, cobalt, lithium, graphite, nickel and manganese is provided in Table 1. It becomes is clear that China has become the most important producer of raw materials for EVs. The country not only has a strong position in the production and processing of REEs and graphite, but also controls the processing of cobalt and lithium, of which it has only small domestic mine production (USGS, 2019c,d).

The strong market position of China brings with it high supply risks for consumers elsewhere as they depend on a stable supply from China. The resulting criticality of the specific raw materials required for EVs is analysed by criticality assessments. The methodology of criticality assessments varies among the various studies, with the major pillar being the analysis of supply risks (BGS, 2015). Most studies also consider the economic importance or vulnerability to supply disruptions as a second dimension (Graedel and Reck, 2016). The two-dimensional approach is applied with individual specifics by the European Commission (2014, 2017), by the USGS (Fortier et al., 2018) pursuant to the Executive Order (EO) No. 13817, “A Federal Strategy to Ensure Secure and Reliable Supplies of Critical Minerals" (The White House, 2017) and for the evaluation of raw material criticality for low carbon energy production in Japan (Miyamoto et al., 2019). Frequently, a third dimension is taken into account to include the environmental impact of a raw material from cradle-to-gate (Graedel et al., 2012, 2015a). Criticality assessments can be region, technology or industry specific, and focus on 
Table 1. Production structure of the CRMs relevant for e-mobility (DERA, 2017a, 2019; Adamas Intelligence as quoted in Law, 2019; USGS, 2019a).

\begin{tabular}{|c|c|c|c|c|}
\hline CRM & Mine production (2018) & Major production & Market share (major producer) & Processing (major country) \\
\hline Rare earths & 170,000 tpy & China & $80 \%$ (LREE) 99\% (HREE) & China \\
\hline Graphite & 930,000 tpy & China & $68 \%$ & China \\
\hline Cobalt & 140,000 tpy & Congo & $64 \%$ & China \\
\hline Lithium & 85,000 tpy & Australia & $60 \%$ & China \\
\hline Manganese & $18,000,000$ tpy & $>10$ countries worldwide & $31 \%$ & Various \\
\hline Nickel & $2,300,000$ tpy & $>15$ countries worldwide & $24 \%$ & Various \\
\hline
\end{tabular}

different organisational levels: thus, one needs to distinguish between potential short-term disruptions and long-term supply risks (Graedel et al., 2012). Furthermore, criticality of raw materials can change over time as new mines are brought into production, substitutes are used and recycling routes are established (Alonso et al., 2012). Accordingly, there cannot be a uniform list of CRMs as Poulton et al. (2013) state.

In recent years, numerous criticality assessments have been conducted to analyse dependencies and bottlenecks along the supply chain, supply risks and potential supply disruptions. In order to identify the most critical raw materials that are required for EVs, results of recent criticality assessments are screened in a meta-analysis. The criticality assessments taken into account include studies from all major economies, the US, Japan, the EU, and its member states with the strongest economies, Germany and the former EU member state, the UK. Results highlight the most critical raw materials.

The raw materials assessed as critical in the supply chain according to these 11 criticality studies between 2013 and 2019 are shown in Fig. 2. Whereas nickel is not considered to be critical in the scientific literature due to its diversified production structure, five of the CRMs that are crucial for EVs were assessed as critical with varying frequency by the different studies: Manganese and lithium were identified as critical by only two and three studies, respectively. Graphite, cobalt and REEs were among the most critical raw materials in recent years. REEs especially were assessed as critical in supply by all the studies, can consequently be regarded as the most critical raw materials and are therefore used as a case study in this paper.

\section{Rare earths as a case study}

Rare earths are a group of 17 chemical elements that comprise the lanthanides plus scandium and yttrium. They have been considered as some of the most critical raw materials that are required for the future of mobility (Alonso et al., 2012). REE usage in automotive applications includes that in permanent magnets, which contain neodymium, praseodymium, dysprosium and sometimes terbium; NiMH batteries, which require lanthanum, cerium and neodymium; and LEDs, which require europium and yttrium. The quantity of REEs vary in different vehicle types. In HEVs, there are usually: $\sim 870-581$ g lanthanum; 1226-821 g cerium; 189-135 g praseodymium; 649-555 g neodymium; and 149-71 g dysprosium (Xu et al., 2016). As the electric drivetrain in a battery electric vehicle (BEV) delivers higher performance than in a HEV, the magnet weight and the overall amount of REEs deployed are usually more than twice as high (Pavel et al., 2017). In contrast, ICE (of a comparable size) require only negligible amounts of REEs (Xu et al., 2016). The need for REEs will consequently increase dramatically as demand grows for BEVs and HEVs. Their production is highly concentrated in China.

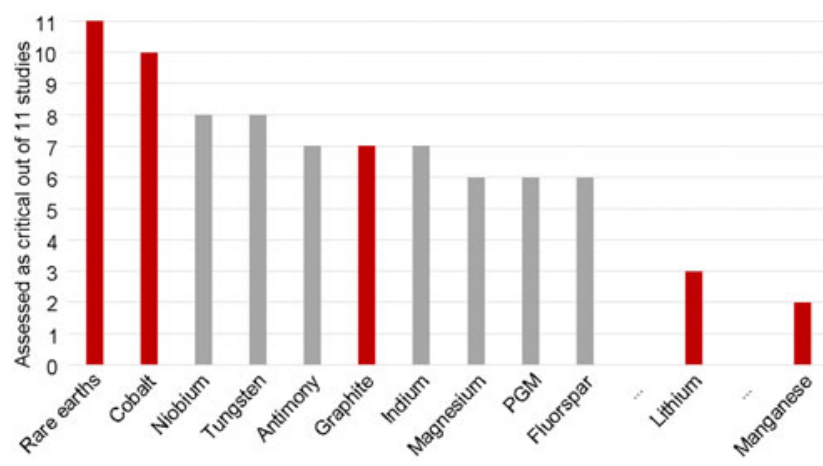

Fig. 2. The most critical raw materials according to 11 recent criticality assessments in Europe, the US and Japan between 2013 and 2019 (Own analysis of Silberglitt et al., 2013; DERA, 2014, 2017b; European Commission, 2014, 2017; BGS, 2015; Hatayama and Tahara, 2015; JOGMEC, 2015 as quoted in Miyamoto et al., 2019; Blagoeva et al., 2016; Fortier et al., 2018; Miyamoto et al., 2019). The red colour indicates those CRMs that are particularly important for EVs.

China's rise in the RE market over recent decades is illustrated in Fig. 3. The US had been the biggest producer of rare earths, accounting for about half of global mine production until the mid-1980s, when China entered the market. The state-capitalistic system followed a systematic plan in order to reach a dominant market position (Mancheri, 2012; Morrison and Tang, 2012; Biedermann, 2014) that the former leader of the People's Republic, Deng Xiaoping, described as follows: "The Middle East has its oil, China has its Rare Earths" (freely quoted in Bradsher, 2009). Within years, the country reached a large market share and became the market leader in terms of production amount in the 1990s, and further strengthened its market position until it had achieved a de facto monopoly in the 2000s. In 2010, China had reached a market share of around $97 \%$. No relevant competitor was left (Fig. 3).

Parallel to the rise of its RE mining industry, China established industries that were based on REEs, for example, phosphors for energy efficient lighting and, above all, a competitive permanent magnet industry that today accounts for $90 \%$ of global $\mathrm{NdFeB}$ magnet production (Adamas Intelligence, 2019; $\mathrm{Du}$ and Graedel, 2013). China has also become competitive in the electric drive technology and is home to some of the biggest manufacturers of EVs worldwide (FT, 2018; Campbell and Tian, 2019). The country now dominates virtually every step along the value chain, leading to concerns about the danger of abuse of market power (Mancheri, 2012).

Having become the dominant player in the RE market, China tightened its export restrictions on REEs in order to attract foreign investments and to strengthen its domestic industry (Tse, 2011; Morrison and Tang, 2012). The market situation for consumers got worse in the years 2010 and 2011: Geo-political tensions 


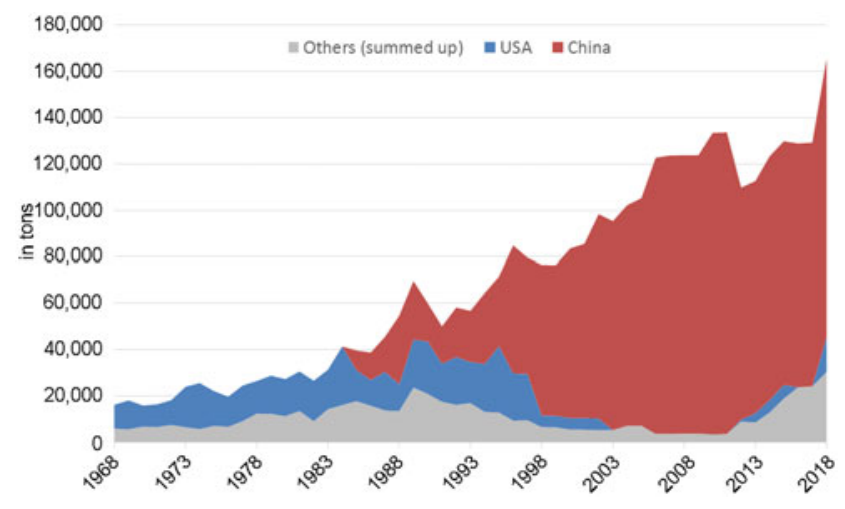

Fig. 3. Global production of rare earths (based on data by USGS, 2019b; in rare earth oxide equivalent content).

between China and Japan escalated when a Chinese fisherman was arrested in a disputed territory over which both countries make claims. China blocked the supply of REEs to Japan for several weeks in retaliation (Bradsher, 2010). Supply disruptions and price increases of several hundred percent were the consequences, causing insecurity in the global market. Consumers of REEs worldwide, in addition to bearing the high costs, were concerned that their supply could become endangered as well and were unsure, whether they could maintain production (Schmid, 2019a, 2020).

The automotive industry, a major user of REEs, was hit particularly hard. Daimler (2011) publicly stressed that the company was exposed to supply risks with regard to REEs due to the high market concentration and the resulting supply dependency. Its direct rival, BMW, confessed that the company suffered under the increased REE prices (Becker, 2018). The German automotive supplier Continental stated that the additional costs due to the RE crisis totalled $€ 30$ million in 2011 (Continental, 2011). Many companies in the automotive industry experienced similar problems (Osram, 2011; Moody's, 2016). Companies were exposed to supply risks mostly regardless of their position in the supply chain and whereas those companies upstream, in the early stages of the supply chain, close to the raw material production, were the first to be affected, price surcharges were often passed on to customers downstream (Hensel, 2011).

The RE crisis in the years 2010 and 2011 illustrated the danger to consumers worldwide of being solely dependent on CRMs from a single supplier. At the same time, to reduce the dependence on China, supply restrictions and price risks have provoked new strategies worldwide, most notably seen in companies seeking access to raw material production, recycling and substitution (Schmid, 2020). Securing direct access to REE mine production outside of China is among the most effective strategies for a stable supply as it ensures the entire raw material need without losses in the quality of the raw material. However, establishing a parallel supply chain outside of China has proven to be challenging (Golev et al., 2014; Schmid, 2019b). The same issue also applies to setting up an industrial recycling route. Recycling of REEs is typically accompanied by a loss of quality of the recyclate (Rademaker et al., 2013; Elwert et al., 2016; Yang et al., 2017). Price competitiveness of secondary raw material is also a major challenge in recycling of REEs and of many CRMs (Binnemans et al., 2013; Ayres, 2019). Losses in the performance of the final product is also a problem that derives from substitution (Widmer et al., 2015; Pavel et al., 2017).
Companies that seek direct access to mine production aim for a diversified supply structure and a reduced dependence on the supply from China. Potential RE projects at different stages can be found worldwide, for example, in Australia, Canada and Malawi (Chen, 2011; Hensel, 2011; Schmid, 2019b). Two major projects outside of China, the Mountain Pass mine in the US and Lynas' Mount Weld in Australia, already produce significant amounts of REEs (Golev et al., 2014; Schmid, 2019b). Different levels of involvement in RE projects can be distinguished, with memoranda of understanding and non-binding offtake agreements being the lowest threshold measures and investing in RE mine projects and setting up joint ventures representing highinvolvement strategies. A larger extent of involvement in RE projects comes together with higher financial investments and increasing risks. However, almost a decade after the RE crisis, no parallel supply chain has been established and the European auto industry is reluctant to engage in $\mathrm{RE}$ projects worldwide (Schmid, 2019b).

The corporate perspective needs to be analysed to understand the challenges and opportunities that the European automotive industry perceives when reacting strategically to $R E E$ criticality and securing their supply.

\section{Methods}

Reconstructing the attitude of companies in the European automotive industry towards securing their access to $R E E$ production and the motivation behind pursuing certain strategies requires a look into the black box of corporate decision-making. Data collection among affected companies in the automotive industry is necessary.

Primary data collection follows a qualitative research design as described in detail in Schmid $(2018,2020)$. Qualitative data - in contrast to quantitative data - help to understand why certain decisions are made, how they are implemented and what the challenges are in pursuing these strategies. The aim is to get a deeper understanding of corporate strategies, motivations and challenges in the implementation process. In order to achieve that, the author conducted in-depth interviews among corporate executives of the European automotive industry in 2016-2019. The majority of the personal interviews took place face-to-face and only a few cases were conducted via telephone. The interviews took 60-120 minutes, which enabled detailed discussion of crucial aspects of mitigating REE supply disruptions. By asking corporate experts about their experiences in the RE market in recent years, and about corporate raw material strategies that help to mitigate supply disruptions and address price risks, this study follows an inductive approach (Eisenhardt, 1989). The research design takes into account the 'big-tent' quality criteria as described by Tracy (2010) in order to ensure, for example, rigor, sincerity and credibility during the qualitative research process.

The interviewees have leading positions in companies. The companies are positioned at different stages along the supply chain of the automotive industry, starting with European car manufacturers (OEMs), including direct suppliers of the OEMs (Tier 1) and ranging to automotive suppliers in the early stages (Tier 2). Usually, a Tier 2 supplier delivers input to the Tier 1 supplier, who supplies a component to the OEM, which then produces the final system. In this paper, a Tier 2 supplier is defined broadly and includes companies in the early stages of the supply chain. This approach follows Ang et al. (2017) who define a supply chain "[...] in which a downstream manufacturer 
(such as Toyota) sources identical critical components from tier 1 suppliers. Those tier 1 suppliers, in turn, source subassemblies or raw materials from tier 2 suppliers." However, the categories are not exclusive, which means that, depending on the product, a Tier 2 supplier can sometimes directly supply certain products to an OEM. At the same time, especially upstream suppliers (Tier 2) and some Tier 1 suppliers only do parts of their business in the automotive industry and are also often active in other industries. The assignment of companies, analysed in this study, along the supply chain, is therefore not a strict classification.

The experts' companies differ in size. The companies range from small- and medium-sized enterprises (SMEs), large suppliers, to big multinational suppliers and OEMs. Whereas NdFeB magnets are the most important application that is investigated, other applications of REEs in the automotive industry (e.g. lighting) were also considered ( $22 \%$ of all companies). The headquarters of the companies are located in different European countries. Within Europe, the German automotive industry is by far the biggest with $\sim 870,000$ employees, which is around four times as much as in France, which is the second biggest car producer in Europe (ACEA, 2018b). This circumstance was also reflected in the choice of companies and corporate experts that were interviewed: a strong focus was put on the German automotive industry without neglecting key players elsewhere in Europe, for example, in France and the UK.

In total, 26 experts from 18 different companies were interviewed to reach theoretical saturation (Corbin and Strauss, 1990). Table 2 provides an overview of the corporate experts that were interviewed according to their function and the position of their company in the supply chain of the automotive industry.

The analysis of the qualitative data and the coding of transcripts was performed on the basis of qualitative data analysis procedure $G A B E K^{\circledast}$ and its software tool WinRELAN ${ }^{\circledast}$ (Buber and Kraler, 2000; Zelger, 2000; Zelger and Oberprantacher, 2002). The $G A B E K^{\circledast}$ method enables the analysis of verbal and textual data and the reconstruction of management decisions (Raich et al., 2014; Schmid, 2020). Results are mostly illustrated using network graphics of associated codes.

\section{Results: The case of rare earths}

\section{Company awareness and preparedness}

Insights into the corporate perspective on REE supply risks reveal a fundamental lack of awareness within the companies at the time of the RE crisis in 2010/2011. Affected companies were hit hard, mostly without prior notice and with little understanding of the actual situation and the effects on their company. The majority of corporate executives that were interviewed stressed that they personally had no or little idea where REEs came from, how they were produced and what the market structure looked like. In a few cases when individuals had already been aware of the supply dependence on China, there was little interest within the firm as REEs and CRMs, in general, were considered to be a niche topic or not relevant at all. This attitude was endemic in most companies at all stages of the supply chain and the lack of awareness could be found in most companies regardless of their size. Large OEMs and major automotive suppliers had little idea of what was in their products or how REEs and REE-based components were produced. Typical answers of corporate experts include: "I've got to admit, that the share of raw material wasn't considered sufficiently." (O17) Due to the lack of awareness of
Table 2. Interviewed experts along the supply pyramid in the automotive industry over the time period: 2016-2019.*

\begin{tabular}{lcc}
\hline & \multicolumn{2}{c}{ Number of interviewed executives } \\
\cline { 2 - 3 } Supplier hierarchy & technical & commercial \\
\hline OEM & 2 & 1 \\
Tier 1 & 12 & 2 \\
Tier 2 & 4 & 4 \\
Others & 1 & \\
\hline
\end{tabular}

*Total of 18 different companies in the European automotive industry. NdFeB as major application: $78 \%$; other applications: $22 \%$.

REE criticality, most companies were not prepared for the situation in 2010/2011. Executives describe that they first had to collect the required information about REEs, their production in China, market structures and particularly the actual $R E E$ content in the companies' products. Typically, the amount of REEs deployed in the final products and the physical properties of certain components were not known. One corporate executive expresses this lack of knowledge pointedly: "No one really knew what was in the magnet." (X19)

Due to the lack of awareness, most (downstream) companies were not prepared for the price and supply risks and only four companies explicitly stated that they had taken proactive measures in advance. Typical answers therefore sound like this: "[We were] not at all prepared for this." (J17)

As the RE crisis hit the affected companies hard, executives themselves, typically, had to gather technical specifications and market information: thus, a timely reaction was difficult to reach. This lack of awareness of criticality and knowledge about REEs and their applications has changed fundamentally since the RE crisis. The experiences in 2010/2011 and in the years after seem to have made an impression - not necessarily as much on the companies' processes and strategies as personally on most corporate executives that were responsible for the implementation of mitigation strategies. Some executives describe sleepless nights that they had due to the price and supply risks endured by their companies. The extent of the increased awareness differs in the various companies in which interviews were conducted, but an overall change of mentality can be observed: "A special kind of serenity has found its way into the company regarding the topic of rare earth." (W18)

Although it is sometimes difficult to keep the topic on the agenda as the automotive industry currently faces many other challenges, for example, car sharing, autonomous driving and digitalisation, according to most executives, today "people are aware" (Y19) of the dependence on REEs from China and the market dominance of the Chinese industry along the value chain.

The resulting supply risks associated with REEs are closely seen in the light of China's state capitalism that is able to plan strategically for the long run. Due to China's strong political influence on the REE market and companies' decisions, the market ratio of profit maximisation does not necessarily apply, according to the interviewed executives. It is argued that Chinese companies along the REE value chain do not have to be profitable, at least in the short term, as long as there is a certain strategic interest in the company or technology perceived by China's policymakers, which are assumed to support these companies. Competition with Chinese companies is further hampered by the cost advantage of China's REE production which ultimately hinders the development of RE projects outside of China. This argument of corporate 
executives occurs frequently and is also related to the lower environmental standards in China, which are also discussed in the scientific literature (Ali, 2014; Packey and Kingsnorth, 2016). Figure 4 illustrates the codes that are associated by the interviewed executives with the dependency on China and the potential consequences for the European automotive industry. China's dominant position in the REE market is closely connected to its state capitalism in which market economy ratio does not apply and which - at least partially - explains the cost advantage of China's REE production, according to the interviewed corporate executives. The low costs and long-term strategy of the Chinese $R E E$ industry is assumed to hinder the development of RE projects outside of China and is seen as a principal reason for the lack of alternatives. In many interviews, corporate executives say that China's RE policy follows a strategic plan to achieve leadership in certain industries. This situation is characterised by one expert as follows: "The Chinese are eating their way into the supply chain from behind." (B19) Dependency on China is therefore not only seen with regard to REE production, but along the entire value chain to separation and further processing, for example, products like NdFeB magnets. Dominance by China is also associated with the threatened decline of technological competence in Europe and with a concern, that companies in the western world will ultimately lose their competitive edge to Chinese companies.

\section{Insights into firm's strategies to secure their supply}

Knowing how to react to the dependency on China is, however, difficult for most companies. Interviewed executives in more than three quarters of the companies stress the high cost pressure in the automotive industry. The fact that the price matters is emphasised numerous times during the interviews and the price of RE and RE-based components seem to be of highest priority. Figure 5 illustrates the strongest associations with the 'price matters'.

According to corporate executives, there are cost advantages to Chinese REE production and there are no comparable and attractive projects outside of China. Any measures to reduce the dependency on China are only assumed to be possible when they are cost competitive, ultimately, with Chinese production. This fundamental requirement narrows the perceived scope for action and limits the possibilities for the companies to engage in RE projects outside China. REEs from elsewhere should cost "not one cent more than [from] China" (G19) is one of the strictest and most straightforward statements that, however, underlines a fundamental challenge expressed by most interviewed executives. Their own reactions to the supply risks and dependencies on China are restricted by this maxim and only limited activities are found within the European industry. In contrast, Japan has been very active in getting involved in RE projects worldwide since the RE crisis and has become the largest competitor to Chinese production through strategic investments in the RE producer Lynas, which has both a RE mine in Australia and a processing plant in Malaysia (Schmid, 2019b). Japan's activities are therefore often considered to be basically the only corrective measures to China's market dominance. The fact that the Australian RE producer Lynas has been in trouble multiple times in recent years due to economic and ecological reasons (Jamaludin and Lahiri-Dutt, 2017), has, consequently, concerned some executives.

Ultimately, price competitiveness seems to dominate the discussion about mitigating supply risks of REEs among many companies, as their customers seem to be unwilling to accept price premiums for REEs from outside of China. Corporate executives also emphasise the feeling that the companies' customers typically tend to have little understanding of the specific REE market situation. There seems to be a lack of strategic interest further down the supply chain and frequently little willingness to consider $R E E$ supply as a strategic topic rather than a merely commercial aspect in a negotiation with the Tier 1 supplier. Surcharges for REE supply from outside of China are mostly not accepted and there is often only little interest in pursuing a long-term oriented strategy, which eventually restricts the ability of the company to act. Among the typical answers that highlight this situation are: "[We] started our discussions with the strategists and then the purchase took over" (X19). "To get an appointment [with the OEM] sometimes takes several months" (A16).

One OEM company executive directly confirms the feeling of many Tier 1 and Tier 2 suppliers that there is little interest in the OEMs to engage in the early stages of the supply chain: "The supplier himself is the one responsible for its risk" (W18). However, most interviewees from both suppliers and OEMs agree that it would be important to establish RE mine projects and to have alternative supply chains outside of China, for example, to use a botanical metaphor: "[We need to] nurse small plants outside of China" (B19). They stress the overall awareness of the topic in their companies and emphasise that alternative RE production and an integrated supply chain outside of China would be important and should be a measure used to reduce the dependency on China. Although most of the interviewed executives acknowledge the need for RE mining projects outside of China and explicitly express their wish for alternative supply chains, only few had taken serious action or have even considered becoming engaged in the early stages of the supply chain, for example, through investments or offtake agreements. The reasons are quite diverse and include the fact that some companies consider themselves too small, that reaction time is too long when trying to establish new projects, that there are overcapacities in China, which threaten the development of parallel supply chains, that there is a lack of real alternatives to Chinese $\mathrm{RE}$ production, that overall success of such a strategy is unlikely and that $R E E$ prices have gone down in recent years, which makes new projects relatively unattractive. Figure 6 illustrates these associations with alternative access to REEs.

Some executives express their hope for future cooperation in order to jointly develop a RE mine project and stress that for big companies, the required investments are relatively small and could be shared: "What is 4 billion for a mine, with all the consumers?" (B19)

However, there are serious doubts among corporate executives that there will be such an initiative and that companies in the automotive industry will actually start to become involved in $\mathrm{RE}$ projects and to engage in the early stages of the supply chain. Even if some players are willing to invest or to participate in a joint action to engage in RE projects outside of China and to establish a parallel value chain, they don't seem to know how to implement that strategy. Although there is wide-spread awareness of the supply risks and of the importance of a long-term strategy, there is also a perceived lack of ability and to some degree, a lack of willingness to engage in RE production among the European automotive industries.

\section{Discussion}

Three major conclusions can be drawn from the data analysis: first, awareness has increased. Whereas at the time of the RE crisis in 2010/2011, most analysed companies in the European 


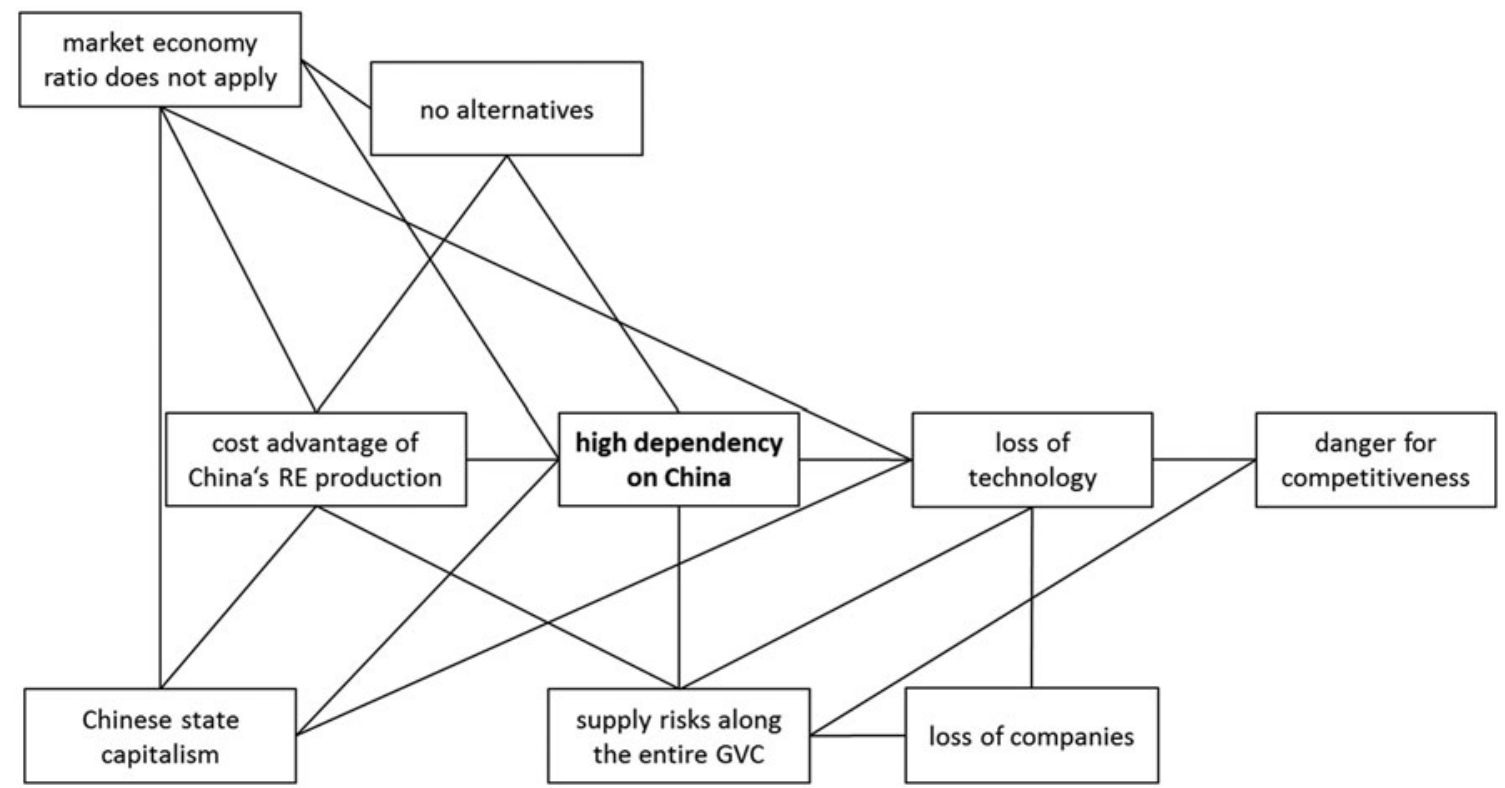

Fig. 4. Association graph of codes related to the dependency on China.

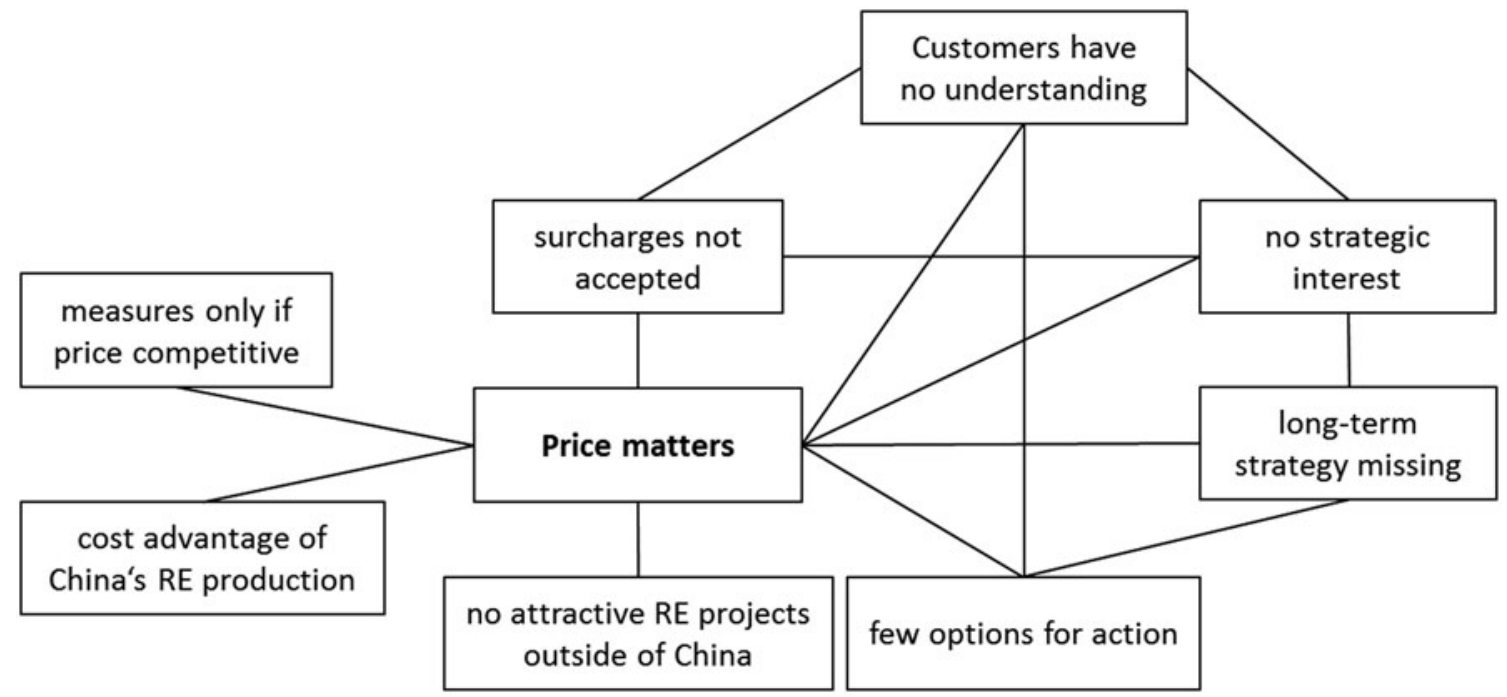

Fig. 5. Association graph of price sensitivity.

automotive industry had been unaware of the supply risks, and surprised by the dependency on China, things have changed fundamentally in recent years. Companies are more aware as criticality of certain raw materials is on the agenda in practically all of the investigated companies: this awareness is the first step in addressing supply risks and enhancing the ability of the companies to mitigate negative market forces.

Second, strategic reactions are perceived to be challenging for the European auto industry as price dominates the discussion. Direct engagements in raw material production through investments in mining companies and RE projects, setting up joint ventures, or signing offtake agreements remain rare for the European auto industry although companies would like to have an alternative supply chain. Companies elsewhere, that were also affected by the RE crisis, have been much more engaged in RE projects, for example, the Japanese companies Mitsubishi, Toyota and Shin-Etsu (Schmid, 2019b). The Japanese car company Toyota has been investing in its raw material supply for a long time through its trading house Toyota Tsusho, which has also been active in investing in RE projects worldwide, for example in Canada, India and Vietnam (Marotte, 2011) "[...] to alleviate the overdependence on rare earths manufactured in China" (Toyota Tsusho, 2015). The same issue applies to the involvement in the production of CRMs in general. A recent initiative of the Japanese automotive industry aims for jointly securing its cobalt demand. Practically all Japanese car manufacturers are considering becoming part of the alliance, which is backed by Japan's Economy, Trade and Industry Ministry (The Japan Times, 2019). Similar plans were announced recently by major automotive manufacturers, such as Tesla, which has stated that it might get into the mining business in order to secure its supply of CRMs required for its EV production (Els, 2019). Ford made a similar statement to the effect that the company is considering investing in cobalt mines in the near future, as it sees the raw 


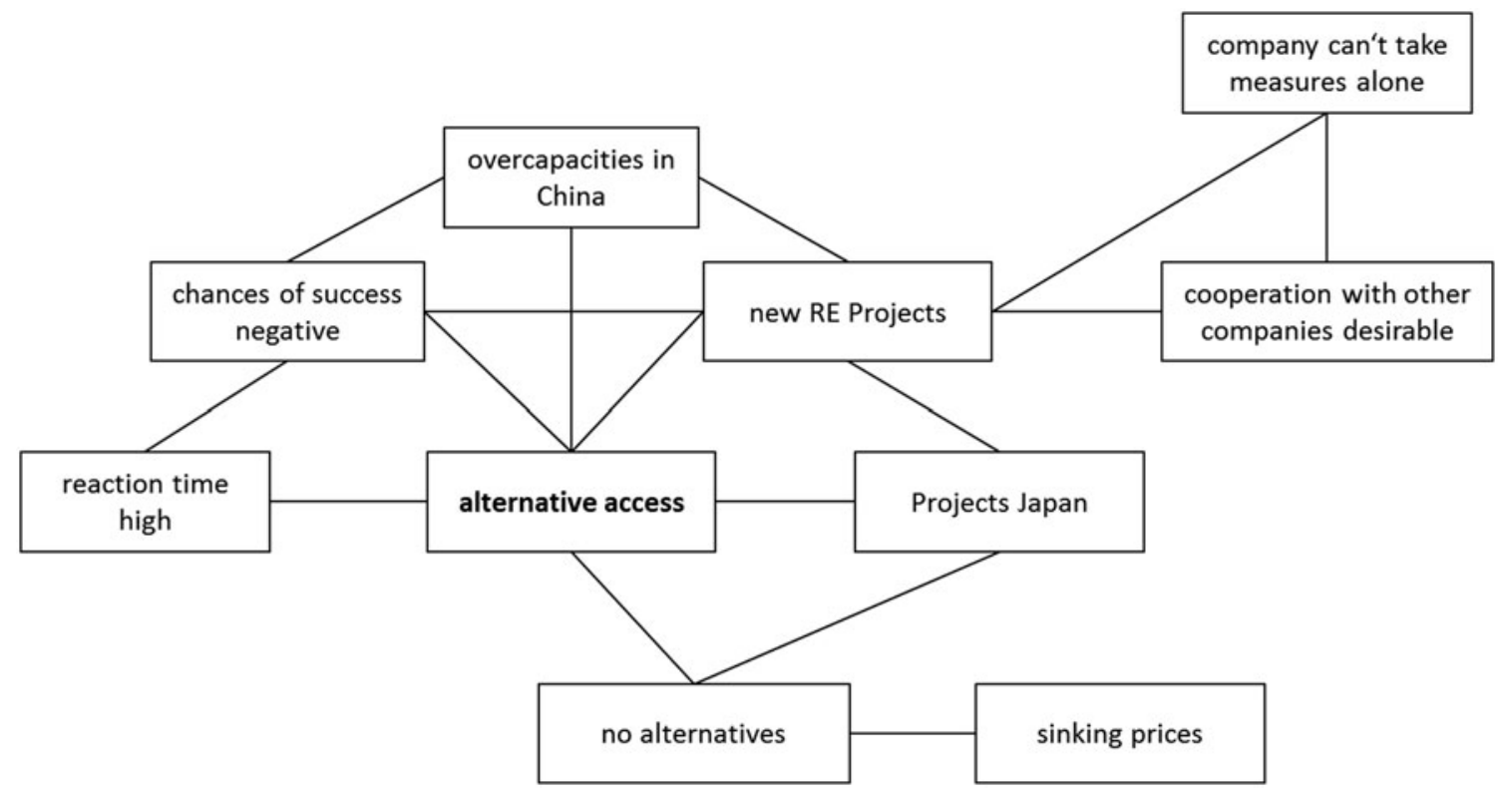

Fig. 6. Association graph of involvement in RE projects outside of China.

material markets being put under pressure by the EV's raw material needs (Jamasmie, 2019).

Third, instead of investing in RE projects, the European auto industry is apparently focusing on substitution (Continental, 2012; motorbrain, 2019; Schmid, 2020; ROMEO, 2019). Substitution attempts to reduce or completely eliminate the exposure to supply risks by replacing REEs. Among the substitutes for $R E E$-based synchronous drives are externally excited synchronous drives, ferrites-based traction drives and asynchronous drives (Smith and Eggert, 2016; Pavel et al., 2017). In the light of the events in 2010 and 2011, BMW announced that its next generation electric drivetrain for its new EVs will be based on technology free of REEs, "making the BMW Group no longer dependent on their availability" (BMW, 2017b). BMW joined forces with British car manufacturer Jaguar Land Rover to develop $R E E$-free drives (Riley, 2019). Turning away from NdFeB permanent magnet-based synchronous drives would also be a change in Jaguar's strategy as its first-ever EV, the Jaguar i-Pace, relies on REEs in its electric motors (Jaguar Land Rover, 2019). The German car manufacturers Audi and Daimler use asynchronous motors also without REEs in their latest EVs (Daimler, 2019; Doerr et al., 2019). Audi highlights the fact that the main advantage of its asynchronous drive is, that it is free of REEs, so there was "[...] no raw material supply risk for the rotor" (Doerr et al., 2019, p. 23). Years before, French car manufacturer Renault had collaborated with Continental and deployed externally excited synchronous motors without REEs in their EVs (Bryant, 2011). The German automotive supplier Bosch also tried to substitute REEs - partially or completely - in its NdFeB magnet applications (MatRessource, 2016). This, however, is not an industry-wide trend as $\sim 90 \%$ of all EVs deploy PM-based drives due to their superior performance (Adamas Intelligence, 2018). Substitution is only one pillar in reducing the dependency on Chinese REEs. Although it may appear logical to substitute for $R E E$ s when their supply is endangered, it is difficult to do so entirely and neither is it a useful strategy in coping with all CRMs that are required for EVs, for example cobalt, lithium and manganese: it is highly unlikely that the European automotive industry will be able to replace all of them in their EVs as most substitutes tend to deliver poorer performance (Graedel et al., 2015b).

These conclusions lead to the following questions:

Do companies need to think more strategically to secure their supply of CRMs?

Do European companies need to collaborate more?

Should European politics become more engaged in CRMs?

The challenge to European governments and businesses is to strategically address criticality: this is of particular importance as China acts strategically and is committed to turn its market power in the early stages of the value chain into dominance in the production of CRM-based components and systems. On the basis of its strong market position in the production of CRMs like REEs, cobalt, graphite and, to a lesser extent, lithium (Table 1), China has strengthened its industries further down the value chain. This competitive advantage reaches to the production of components, for example, China has achieved market dominance in the production of $\mathrm{NdFeB}$ permanent magnets that contain neodymium, dysprosium and terbium. In the case of cobalt, the same applies to lithium-ion-battery (LIB) production, where Chinese companies are also taking the lead (Bloomberg, 2018, Holzmann, 2018; Ma et al., 2018). The consequences of this market dominance are far-reaching for the automotive industry. Toyota, which is very active in the early stages of the value chain, had to admit that - although it considers itself to be a producer of batteries for EVs - it is not able to meet its own demand and that it will rely on batteries from Chinese battery producers BYD and CATL in the future (Buckland and Tajitsu, 2019). China's strong position now stretches from mine production, refining, separation and further processing, to battery and electric drive production, and EV production as many Chinese companies are among the most promising EV manufacturers (Campbell and Tian, 2019). The challenges associated with CRMs might therefore even increase, as dependencies tend to expand to later stages of the value chain. Faced with these challenges and new competitors, it seems to be understandable that many executives stated that strategies, which include obtaining a supply of REEs from 
projects outside of China, can only be pursued when they do not lead to cost increases. However, OEMs, especially, should question whether there is a lack of ability or a lack of willingness to pay strategic surcharges.

Cooperation along the supply chain could help to meet these strategic challenges. In the aftermath of the RE crisis, a German consortium, the German Raw Material Alliance, was founded. The organisation aimed to develop mine projects and to invest in mines in order to secure the supply of CRMs for its members. The latter included the German OEMs BMW, Volkswagen, and the automotive suppliers Bosch and Thyssenkrupp (Handelsblatt, 2012). However, the initiative failed and the organisation was dissolved in 2015. That was a remarkable turn of events, as many automotive industry companies and governments outside of Europe have been more active in developing RE projects and investing in mine production. In particular, Japan and its domestic automotive industry have been much more engaged in securing direct access, for example, to RE production (Hilpert and Mildner, 2013; Barteková and Kemp, 2016; Mancheri and Marukawa, 2016; Schmid, 2019b).

As others have stepped up, the consequences of a potential loss of technological capabilities and competitiveness in Europe are unlikely to have a negative effect on the adoption of EVs worldwide nor is it to be expected that the decarbonisation of the global mobility market will be hindered by these challenges faced by the European automotive industry. However, as the path of many car manufacturers to an all-electric future will be based on REEs and other CRMs, a stable and price competitive supply of raw materials and components based on them (especially the drivetrain and the battery) will be crucial for all European companies - from upstream suppliers to the OEMs. If the European automotive industry fails to mitigate existing price and supply risks and to develop a strategic response to the concentrated markets, a further shift of global value chains is likely to those regions, especially China, where supply of CRMs is treated as a long-term strategic issue, which could lead to negative consequences for individual European companies. Ultimately, Europe's economic prosperity could suffer as a result with potentially negative effects on the labour market.

Due to the political dimension of this challenge and the difficulties faced by the European automotive industry in addressing them, the question needs to be raised, whether European politics needs to become more involved in supporting European companies in mine production and in the upstream stages of the supply chain of CRMs. Politicians of the EU could thereby learn from the political measures in Japan and the US, which both faced similar challenges with regard to the supply of REEs and CRMs in general.

In Japan, the Japan Oil, Gas and Metals National Corporation is a so-called incorporated administrative agency that drives mine projects worldwide in order to secure a stable supply of raw materials for Japan, for example though exploration activities, mine development, project financing and stockpiling of strategic raw materials (JOGMEC, 2018). Numerous Japanese activities are (financially) backed by the JOGMEC. JOGMEC has also got involved in many RE projects worldwide in recent years (Schmid, 2019b) and promptly budgeted US-\$ 650 million for the year 2011, in the aftermath of the RE crisis, to mitigate supply risks for Japan's economy (Reuters, 2011). The strong political engagement in the RE and CRM markets has proven to be successful in terms of reducing supply dependency and mitigating supply risks (Schmid, 2019b). The US are seemingly trying to follow Japan's example: the US Department of Defense (US DoD) is currently funding a REE processing plant (Reuters, 2019a) and is in talks with Australia to ensure supply with REEs for military applications (Reuters, 2019b). Furthermore, the current US administration is also trying to establish an organisation, similar to Japan's JOGMEC, which has started to examine potential raw materialrelated investments through the Overseas Private Investment Corporation (OPIC) (Chowdhury, 2019; Peak Resources, 2019).

To date, there is no equivalent European organisation. Results of this study suggest, that such an organisation could be an important political pillar in a European mitigation strategy to support corporate measures that aim for a reliable supply of CRMs for EVs.

\section{Conclusion}

Value creation of EVs is highly dependent on CRMs. Market power in the early stages of the value chain will be a major competitive advantage in the automotive industry in the future. Market dominance in the production of CRMs can also be used for political purposes. In 2019, during the trade dispute between China and the US, China threatened to restrict exports of rare earths and rare-earth-based components to the US. When the trade dispute between China and the US threatened to escalate, China seemed to be ready to use its dominant market position in RE production as leverage in the trade conflict (Blanchard et al., 2019; Bodeen, 2019; Zheng, 2019). The current development resembles the first rare earth crisis of a decade ago (Schmid, 2019a). The last decade as well as current trade disputes between the US and China have shown that critical raw materials can quickly be used as an advantage and supply can be restricted for consumers worldwide.

The recurring supply risks highlight how fragile the supply chains of CRMs are. As the automotive industry is increasingly becoming one of the biggest consumers of some of the most critical raw materials in their transformation to an all-electric future, this dependency adds high risks to their business. As described in this paper, the European automotive industry seems not entirely prepared for that challenge: results from the case study on REEs underline that the awareness of the relevance of CRMs has undoubtedly increased in recent years, but the challenges of implementing a consistent corporate raw material strategy have also become obvious. Strategic reactions are recognised as important and can be observed in many parts of the European automotive industry, but their implementation is proving to be difficult. Pursuing long-term oriented raw material strategies in a competitive market environment remains challenging, as there is often a lack of ability or willingness to pay (strategic) surcharges for REEs from outside of China. European companies are also avoiding involvement in mine production and there seems to be a lack of willingness or ability to commit to long-term investments. These findings raise the questions whether the industry requires a new mindset and if a more active political role by the European Union is necessary.

Acknowledgements. This research received funding by Ministerium für Wirtschaft, Wissenschaft und Digitalisierung des Landes Sachsen-Anhalt, Germany (grant number I 108). The author thanks the anonymous reviewers and the editors.

\section{References}

ACEA (2018a) The Automotive Industry. Pocket Guide 2018-2019. European Automobile Manufacturers Association https://www.acea.be/uploads/publications/ACEA_Pocket_Guide_2018-2019.pdf [Accessed 26.06.2019]. 
ACEA (2018b) Employment Trends in the EU Auto Industry. European Automobile Manufacturers Association, 21.06.2018, https://www.acea.be/ statistics/article/employment [Accessed 09.07.2019].

ACEA (2019) Economic and Market Report. EU Automotive Industry. Fullyear 2018. European Automobile Manufacturers Association, February 2019, https://www.acea.be/uploads/statistic_documents/Economic_and_ Market_Report_full-year_2018.pdf [Accessed 26.06.2019].

Adamas Intelligence (2018) Spotlight on Dysprosium: Revving Up for Rising Demand. April 2018, https://www.adamasintel.com/spotlight-on-dysprosium/ [Accessed 25.08.2019].

Adamas Intelligence (2019) Rare Earth Elements: Market Issues and Outlook. June 2019, https://www.adamasintel.com/report/rare-earth-elements-market-issues-and-outlook/ [Accessed 28.01.2020].

Ali S.H. (2014) Social and environmental impact of the rare earth industries. Resources, 3, 123-134.

Alonso E., Sherman A.M., Wallington T.J., Everson M.P., Field F.R., Roth R. and Kirchain R.E. (2012) Evaluating rare earth element availability: A case with revolutionary demand from clean technologies. Environmental Science \& Technology, 46, 3406-3414.

Altenburg T., Schamp E.W. and Chaudhary A. (2015) The emergence of electromobility: Comparing technological pathways in France Germany China and India. Science and Public Policy, 43, 464-475.

Ang E., Iancu D.A. and Swinney R. (2017) Disruption risk and optimal sourcing in multitier supply networks. Management Science, 63, 2397-2419.

Ayres R.U. (2019) The business case for conserving rare metals. Technological Forecasting and Social Change, 143, 307-315.

Barteková E. and Kemp R. (2016) National strategies for securing a stable supply of rare earths in different world regions. Resources Policy, 49, 153-164.

Becker J. (2018) Das Übertrumpfen geht schon los. (The trumping is already going on). Süddeutsche Zeitung 07.05.2018, https://www.sueddeutsche.de/ auto/elektromobilitaet-das-uebertrumpfen-geht-schon-los-1.3964354 [Accessed 16.07.2019, in German].

BGS (2015) Risk List 2015. British Geological Survey, https://www.bgs.ac.uk/ downloads/start.cfm?id=3075 [Accessed 09.07.2019].

Biedermann R.P. (2014) China's rare earth sector-between domestic consolidation and global hegemony. International Journal of Emerging Markets, 9, 276-293.

Binnemans K., Jones P.T., Blanpain B., Van Gerven T., Yang Y., Walton A. and Buchert M. (2013) Recycling of rare earths: a critical review. Journal of Cleaner Production, 51, 1-22.

Blagoeva D.T., Aves Dias P., Marmier A. and Pavel C. (2016) Assessment of potential bottlenecks along the materials supply chain for the future deployment of low-carbon energy and transport technologies in the EU. Wind power photovoltaic and electric vehicles technologies time frame 2015-2030. European Commission - Joint Research Centre (EU COM JRC, editors). https://setis.ec.europa.eu/sites/default/files/reports/materials_supply_bottleneck.pdf, doi:10.2790/08169.

Blanchard B., Martina M. and Daly T. (2019) China Ready to Hit Back at U.S. With Rare Earths: Newspapers. Reuters 29.05.2019, https://www.reuters. com/article/us-usa-trade-china-rareearth/china-ready-to-hit-back-at-u-swith-rare-earths-ruling-party-newspaper-idUSKCN1SZ07V [Accessed 31.05.2019].

Bloomberg (2018) Here Are the Firms Feeding China's Battery Revolution. 18.03.2018, https:/www.bloomberg.com/news/articles/2018-03-18/hereare-the-firms-feeding-china-s-battery-revolution [Accessed 30.01.2020].

BloombergNEF (2019) Electric Transport Revolution Set To Spread Rapidly Into Light and Medium Commercial Vehicle Market. 15.05.2019, https:// about.bnef.com/blog/electric-transport-revolution-set-spread-rapidly-lightmedium-commercial-vehicle-market/ [Accessed 20.01.2020].

BMW (2017a) BMW Group invests 200 million euros in Battery Cell Competence Centre. BMW Group 24.11.2017 https://www.press.bmwgroup. com/global/article/detail/T0276448EN/bmw-group-invests-200-millioneuros-in-battery-cell-competence-centre?language $=$ en [Accessed 16.07.2019].

BMW (2017b) BMW $i$ in the Summit-Club of the Electric Mobility World. BMW Group 20.12.2017 https://www.press.bmwgroup.com/global/article/ detail/T0277324EN/bmw-i-in-the-summit-club-of-the-electric-mobilityworld?language $=$ en [Accessed 30.05.2018].
Bodeen C. (2019) China blames US for trade dispute, but doesn't escalate. The Associated Press, 03.06.2019 https://apnews.com/f2f3c0e49d94465a942 cb5d8c6b712ae [Accessed 19.02.2020].

Boldea I., Tutelea L.N., Parsa L. and Dorrell D. (2014) Automotive electric propulsion systems with reduced or no permanent magnets: An overview. IEEE Transactions on Industrial Electronics, 61, 5696-5711.

Bradsher K. (2009) China Tightens Grip on Rare Minerals. The New York Times, 31.08.2009, http:/www.nytimes.com/2009/09/01/business/global/ 01minerals.html [Accessed 24.07.2017].

Bradsher K. (2010) Amid Tension China Blocks Vital Exports to Japan. The New York Times, 22.09.2010, http://www.nytimes.com/2010/09/23/business/ global/23rare.html [Accessed 24.07.2017].

Bryant C. (2011) Industry Explores Rare Earth Options. Financial Times, 02.11.2011, https://www.ft.com/content/c70e916e-f4c1-11e0-a286-00144feab49a [Accessed 25.07.2019].

Buber R. and Kraler C. (2000) How GABEK and WinRelan support qualitative research. Pp. 111-137 in: GABEK II. Zur Qualitativen Forschung - On Qualitative Research (Buber, R. and Zelger, J. editors). Studienverlag, Innsbruck, Wien, Austria.

Buckland K. and Tajitsu N. (2019) Toyota Speeds Up Electric Vehicle Schedule As Demand Heats Up. Reuters Business News, 07.06.2019, https://www. reuters.com/article/us-toyota-electric/toyota-speeds-up-electric-vehicleschedule-as-demand-heats-up-idUSKCN1T806X [Accessed 16.07.2019].

Campbell M. and Tian Y. (2019) The World's Biggest Electric Vehicle Company Looks Nothing Like Tesla. Bloomberg Businessweek, 16.04.2019, https:// www.bloomberg.com/news/features/2019-04-16/the-world-s-biggest-electricvehicle-company-looks-nothing-like-tesla [Accessed 16.07.2019].

Cano Z.P., Banham D., Ye S., Hintennach A., Lu J., Fowler M. and Chen Z. (2018) Batteries and fuel cells for emerging electric vehicle markets. Nature Energy, 3, 279-289.

Carey N. and White J. (2018) Ford Plans \$11 Billion Investment 40 Electrified Vehicles By 2022. Reuters, 14.01.2018 https://www.reuters.com/article/usautoshow-detroit-ford-motor/ford-plans-11-billion-investment-40-electrifiedvehicles-by-2022-idUSKBN1F30YZ [Accessed 26.06.2019].

Chen Z. (2011) Global rare earth resources and scenarios of future rare earth industry. Journal of Rare Earths, 29, 1-6.

Chowdhury, H. (2019) US Government Taps UK Firm To Secure Rare Metals. The Telegraph, 22.04.2019, https:/www.telegraph.co.uk/technology/2019/04/22/us-government-taps-uk-firm-secure-rare-metals/ [Accessed 02.02.2020].

Continental (2011) Annual Report 2011. https://www.continental-corporation com/resource/blob/10966/1b2c0317de9495152134debd50b1e793/annualreport-2011-data.pdf [Accessed 08.07.2019].

Continental (2012) Electric Vehicle Expertise from a Single Source. Press Release, 13.08.2012 https://www.continental-corporation.com/en/press/pressreleases/electric-vehicle-expertise-from-a-single-source-8416 [Accessed 16.07.2019].

Corbin J. and Strauss A. (1990) Grounded theory research: procedures canons and evaluative criteria. Qualitative Sociology, 13, 3-21.

Daimler (2019) The Mercedes-Benz EQC. Press Information, 15.05.2019. https:// media.daimler.com/marsMediaSite/ko/en/43358960 [Accessed 16.07.2019].

Daimler (2011) Annual Report 2011. https://www.daimler.com/documents/ investors/berichte/geschaeftsberichte/daimler/daimler-ir-annualreport-2011. pdf [Accessed 26.07.2017].

de Koning A., Kleijn R., Huppes G., Sprecher B., van Engelen G. and Tukker A. (2018) Metal supply constraints for a low-carbon economy? Resources Conservation and Recycling, 129, 202-208.

DERA (2014) DERA-Rohstoffliste 2014: Angebotskonzentration bei mineralischen Rohstoffen und Zwischenprodukten - potenzielle Preis- und Lieferrisiken. [DERA Raw Materials List 2014: Supply concentration of mineral raw materials and intermediate products - potential price and supply risks.] DERA Rohstoffinformationen, 24. Deutsche Rohstoffagentur. https:// www.deutsche-rohstoffagentur.de/DE/Gemeinsames/Produkte/Downloads/ DERA_Rohstoffinformationen/rohstoffinformationen-24.pdf;jsessionid= 6DD0C09903F0C2052DF38273F409D9EE.1_cid331?_blob=publicationFile\& $\mathrm{v}=4$ [Accessed 09.07.2019, in German]

DERA (2017a) Cobalt from the DR Congo - Potential Risks and Significance for the global Cobalt market. Deutsche Rohstoffagentur Commodity TopNews 
53 (S. Al Barazi, U. Näher, S. Vetter, P. Schütte, M. Liedtke, M. Baier and G. Franken). https://www.deutsche-rohstoffagentur.de/DE/Gemeinsames/ Produkte/Downloads/Commodity_Top_News/Rohstoffwirtschaft/53_kobaltaus-der-dr-kongo_en.pdf?_blob=publicationFile\&v $=6$ [Accessed 10.07.2019].

DERA (2017b) DERA-Rohstoffliste 2016: Angebotskonzentration bei mineralischen Rohstoffen und Zwischenprodukten - potenzielle Preis- und Lieferrisiken. [DERA Raw Materials List 2016: Supply concentration of mineral raw materials and intermediate products - potential price and supply risks.] DERA Rohstoffinformationen 32. Deutsche Rohstoffagentur. https://www.deutsche-rohstoffagentur.de/DERA/DE/Downloads/rohstoffliste-2016.pdf?__blob=publicationFile [Accessed 09.07.2019, in German].

DERA (2019) DERA - Rohstoffliste 2019: Angebotskonzentration bei mineralischen Rohstoffen und Zwischenprodukten - potenzielle Preis- und Lieferrisiken [DERA Raw Materials List 2019: Supply Concentration of Mineral Raw Materials and Intermediate Products - Potential Price and Supply Risks.] DERA Rohstoffinformationen, 40. Deutsche Rohstoffagentur. https://www.deutsche-rohstoffagentur.de/DE/Gemeinsames/ Produkte/Downloads/DERA_Rohstoffinformationen/rohstoffinformationen-40. pdf;jsessionid=9AEF36B9F02A69F250E9406B36C8BC01.2_cid284?_blob= publicationFile\&v $=5$ [Accessed 09.08.2019, in German].

Desai P. (2017) Volkswagen's Talks With Cobalt Producers End Without Deal. Reuters, 27.11.2017, https://www.reuters.com/article/us-volkswagen-cobalt/ volkswagens-talks-with-cobalt-producers-end-without-dealidUSKBN1DR1ZL [Accessed 08.07.2019].

Desai P. (2018) Tesla's Electric Motor Shift To Spur Demand For Rare Earth Neodymium. Reuters, 12.03.2018 https://www.reuters.com/article/usmetals-autos-neodymium-analysis/teslas-electric-motor-shift-to-spur-demandfor-rare-earth-neodymium-idUSKCN1GO28I [Accessed 26.06.2019].

Dijk M., Orsato R.J. and Kemp R. (2013) The emergence of an electric mobility trajectory. Energy Policy, 52, 135-145.

Doerr J., Ardey N., Mendl G., Fröhlich G., Straßer R. and Laudenbach T. (2019) The new full electric drivetrain of the Audi e-tron. Pp. 13-37 in: Der Antrieb von Morgen 2019 (J. Liebl, editor). Springer Vieweg Wiesbaden,

$\mathrm{Du}$ X. and Graedel T.E. (2013) Uncovering the end uses of rare earth elements. Science of the Total Environment, 461-462, 781-784.

Eisenhardt K.M. (1989) Building theories from case-study research. Academy of Management Review, 14, 532-550.

Els F. (2019) Elon Musk says Tesla "might get into mining". mining.com, 17.06.2019, https://www.mining.com/elon-musk-says-tesla-might-get-intomining/ [Accessed 26.06.2019].

Elwert T., Goldmann D., Roemer F. and Schwarz S. (2016) Recycling of NdFeB magnets from electric drive motors of (hybrid) electric vehicles. Journal of Sustainable Metallurgy, 3, 108-121.

Erdmann L., Bette K., Merino J.M. and Velte D. (2015) Roadmap for the Substitution of Critical Raw Materials in Electric Motors and Drives. CRM_InnoNet Substitution of Critical Raw Materials May 2015. https:// www.isi.fraunhofer.de/content/dam/isi/dokumente/ccv/2015/Roadmap-forCRM-substitution_Electric_Motors_And_Drives.pdf [Accessed 24.07.2019].

European Commission (2014) Report on Critical Raw Materials for the EU: Report of the Ad hoc Working Group on Defining Critical Raw Materials. May 2014. https://ec.europa.eu/docsroom/documents/10010/attachments/ 1/translations/en/renditions/pdf [Accessed 09.07.2019].

European Commission (2017) Study on the Review of the List of Critical Raw Materials. Criticality Assessments. Directorate-General for Internal Market Industry Entrepreneurship and SMEs June 2017. https://publications.europa.eu/s/dZ7O [Accessed 03.11.2017].

Evans S. (2019) The Tesla Model 3 Long Range Dual Motor is Quicker Than You Think. Motortrend, 04.06.2019, https://www.motortrend.com/cars/ tesla/model-3/2018/2018-tesla-model-3-long-range-dual-motor-first-testreview/ [Accessed 24.07.2019].

Ewing J. (2017) What Needs to Happen Before Electric Cars Take Over the World. The New York Times, 18.12.2017 https://www.nytimes.com/2017/ 12/18/business/electric-car-adoption.html [Accessed 01.07.2019].

Fortier S.M., Nassar N.T., Lederer G.W., Brainard J., Gambogi J. and McCullough E.A. (2018) Draft Critical Mineral List - Summary of Methodology and Background Information. U.S. Geological Survey technical input document in response to Secretarial Order No. 3359: U.S. Geological Survey Open-File Report 2018-1021. https://doi.org/10.3133/ofr20181021.
FT (2018) Foreign Electric Cars Favored In China But Shakeout Looms. FT Confidential Research Nikkei Asian Review, 20.03.2018 https://asia.nikkei. $\mathrm{com} /$ Features/FT-Confidential-Research/Foreign-electric-cars-favored-inChina-but-shakeout-looms [Accessed 16.07.2019].

GM (2019) GM Technology Paves the Way for an All-Electric Future. General Motors https://www.gm.com/our-stories/technology/gm-technology-pavesthe-way-for-an-all-electric-future.html [Accessed 26.06.2019].

Golev A., Scott M., Erskine P.D., Ali S.H. and Ballantyne G.R. (2014) Rare earths supply chains: Current status, constraints and opportunities. Resources Policy, 41, 52-59.

Graedel T.E., Barr R., Chandler C., Chase T., Choi J., Christoffersen L., Friedlander E., Henly C., Jun C., Nassar N.T., Schechner D., Warren S., Yang M.-Y. and Zhu C. (2012) Methodology of metal criticality determination. Environmental Science \& Technology, 46, 1063-1070.

Graedel T.E., Harper E.M., Nassar N.T., Nuss P. and Reck B.K. (2015a) Criticality of metals and metalloids. Proceedings of the National Academy of Sciences, 112, 4257-4262.

Graedel T.E., Harper E.M., Nassar N.T. and Reck B.K. (2015b) On the materials basis of modern society. Proceedings of the National Academy of Sciences, $112,6295-6300$.

Graedel T.E. and Reck B.K. (2016) Six years of criticality assessments: what have we learned so far? Journal of Industrial Ecology, 20, 692-699.

Grandell L., Lehtilä A., Kivinen M., Koljonen T., Kihlman S. and Lauri L.S. (2016) Role of critical metals in the future markets of clean energy technologies. Renewable Energy, 95, 53-62.

Handelsblatt (2012) BMW und VW treten Rohstoffallianz bei [BMW and VW join raw material alliance]. 18.12.2012 https://www.handelsblatt.com/unternehmen/energie/automobilkonzerne-bmw-und-vw-treten-rohstoffallianzbei/7537438.html [Accessed 16.07.2019, in German].

Hardman S., Steinberger-Wilckens R. and Van Der Horst D. (2013) Disruptive innovations: the case for hydrogen fuel cells and battery electric vehicles. International Journal of Hydrogen Energy, 38, 15438-15451.

Hatayama H. and Tahara K. (2015) Criticality Assessment of Metals for Japan's Resource Strategy. Materials Transactions, 56, 229-235.

Hensel N.D. (2011) Economic challenges in the clean energy supply chain: the market for rare earth minerals and other critical inputs. Business Economics, 46, 171-184.

Hilpert H.G. and Mildner S.-A. (2013) Fragmentation or Cooperation in Global Resource Governance? A Comparative Analysis of the Raw Materials Strategies of the G20. SWP Research Paper 150-157. https://www.swp-berlin.org/fileadmin/contents/products/research_papers/ 2013_RP01_hlp_mdn.pdf [Accessed 13.03.2019].

Holzmann A. (2018) China's Battery Industry Is Powering Up For Global Competition. MERICS Economic Indicators Q3/2018 Quarterly analysis of economic trends in China 4-6. https://www.merics.org/sites/default/files/ 2018-10/181024_Q3\%20Economic\%20indicators_0.pdf [Accessed 16.07.2019].

Hyundai (2018) All-New Hyundai Kona Electric - Technical Data and Dimensions. 09.07.2018 https://www.hyundai.news/eu/press-kits/all-newhyundai-kona-electric-technical-data-and-dimensions/ [Accessed 24.07.2019].

IEA (2017) Global EV Outlook 2017. Two Million and Counting. International Energy Agency Clean Energy Ministerial Electric Vehicles Initiative. https:// www.oecd.org/publications/global-ev-outlook-2017-9789264278882-en.htm [Accessed 19.06.2019].

IEA (2018) Global EV Outlook 2018. Towards Cross-Modal Electrification. International Energy Agency Clean Energy Ministerial Electric Vehicles Initiative. https://www.iea.org/gevo2018/ [Accessed 19.06.2019].

IEA (2019) Global EV Outlook 2019. International Energy Agency. https:// www.iea.org/gevo2019/ [Accessed 19.06.2019].

Jaguar Land Rover (2019) All-Electric Jaguar I-Pace. https://www.jaguar.co.uk/ request-a-brochure/index.html [Accessed 16.07.2019].

Jamaludin, H. and Lahiri-Dutt, K. (2017) Could Lynas make a difference in the global political economy of Rare Earth Elements in future? Resources Policy, 53, 267-273.

Jamasmie C. (2019) Ford says carmakers may need to invest in cobalt mines soon. Mining.com, 05.02.2019 https://www.mining.com/ford-says-carmakers-may-need-invest-cobalt-mines-soon/ [Accessed 10.07.2019].

JOGMEC (2018) Annual Report 2018. Japan Oil, Gas and Metals National Corporation, http://www.jogmec.go.jp/content/300350621.pdf [Accessed 02.02.2020]. 
Jussani A.C., Wright J.T.C. and Ibusuki U. (2017) Battery global value chain and its technological challenges for electric vehicle mobility. RAI Revista de Administração e Inovação, 14, 333-338.

Kester J., Noel L., de Rubens G.Z. and Sovacool B.K. (2018) Policy mechanisms to accelerate electric vehicle adoption: a qualitative review from the Nordic region. Renewable and Sustainable Energy Reviews, 94, 719-731.

Law Y.-H. (2019) Radioactive waste standoff could slash high tech's supply of rare earth elements. Science, 01.04.2019, https://doi.org/10.1126/science.aax5411.

Ma J., Stringer D., Zhang Y. and Kim S. (2018) The Breakneck Rise of China's Colossus of Electric-Car Batteries. Bloomberg Businessweek, 01.02.2018, https://www.bloomberg.com/news/features/2018-02-01/the-breakneck-riseof-china-s-colossus-of-electric-car-batteries [Accessed 30.01.2020].

Mancheri N.A. (2012) Chinese monopoly in rare earth elements: supplydemand and industrial applications. China Report, 48, 449-468.

Mancheri N.A. and Marukawa T. (2016) Rare Earth Elements: China and Japan in Industry Trade and Value Chain. ISS Contemporary Chinese Research Series No.17 March 2016. Institute of Social Science University of Tokyo.

Marchionne S. (2013) Chrysler Group's Sergio Marchionne Addresses Industry Leaders at 2013 SAE World Congress Annual Banquet. Fiat Chrysler Automobiles, 18.04.2013 http://media.fcanorthamerica.com/newsrelease.do \%3bjsessionid $=7280$ A9639890EB4B9CDD623851A79EA2? \&id $=14133 \&$ mid $=2$ [Accessed 06.11.2017].

Marotte B. (2011) Toyota Teams Up With Miner In Rare-Earth Minerals Deal. The Globe and Mail, 13.12.2011 https://www.theglobeandmail.com/reporton-business/industry-news/energy-and-resources/toyota-teams-up-withminer-in-rare-earth-minerals-deal/article4180913/ [Accessed 16.07.2019].

MatRessource (2016) Neue Permanentmagnetmaterialien für die Ressourceneffizienz - kostengünstig und seltenerdmetallfrei/-reduziert. [New permanent magnet materials for resource efficiency - low cost and rare earth metal free / reduced]. Verbundprojekt „Perfekt” BMBF https://matressource.de/fileadmin/user_upload/Poster_2016/2016-08-03-Poster-Perfekt03XP0023A-Juergen_Oberle.pdf [Accessed 16.07.2019, in German].

Miyamoto W., Kosai S. and Hashimoto S. (2019) Evaluating metal criticality for low-carbon power generation technologies in Japan. Minerals, 9, 95

Moody's (2016) Annual Update, 09.05.2016 [S.A. Valeo], https://www.valeo. com/wp-content/uploads/2016/11/moody-s-credit-opinion-on-may-05-2016. pdf [Accessed 08.07.2019].

Morrison W.M. and Tang R. (2012) China's Rare Earth Industry and Export Regime: Economic and Trade Implications for the United States. CRS Report for Congress Congressional Research Service 7-5700 R42510 30.04.2012 https://fas.org/sgp/crs/row/R42510.pdf [Accessed 03.07.2019].

motorbrain (2019) Project. http://motorbrain.eu/ [Accessed 16.07.2019].

Nykvist B. and Nilsson M. (2015) Rapidly falling costs of battery packs for electric vehicles. Nature Climate Change, 5, 329-332.

Olivetti E.A., Ceder G., Gaustad G.G. and Fu X. (2017) Lithium-ion battery supply chain considerations: analysis of potential bottlenecks in critical metals. Joule, 1, 229-243.

Ortego A., Valero A., Valero A. and Restrepo E. (2018) Vehicles and critical raw materials: A sustainability assessment using thermodynamic rarity. Journal of Industrial Ecology, 22, 1005-1015.

Osram (2011) Customer Information on Rare Earths, August 2011. http://www. osram.com/media/resource/HIRES/333009/264096/pdf_OSRAMCustomer_ information_rare_earth_metals_eng.pdf [Accessed 02.02.2020].

Packey D.J. and Kingsnorth D. (2016) The impact of unregulated ionic clay rare earth mining in China. Resources Policy, 48, 112-116.

Pavel C.C., Thiel C., Degreif S., Blagoeva D., Buchert M., Schüler D. and Tzimas E. (2017) Role of substitution in mitigating the supply pressure of rare earths in electric road transport applications. Sustainable Materials and Technologies, 12, 62-72.

Peak Resources (2019) USA shows interest in Ngualla Rare Earth Project. ASX Announcement, 26.11.2019. https://wcsecure.weblink.com.au/pdf/PEK/ 02177595.pdf [Accessed 02.02.2020].

Pollet B.G., Staffell I. and Shang J.L. (2012) Current status of hybrid battery and fuel cell electric vehicles: From electrochemistry to market prospects. Electrochimica Acta, 84, 235-249.

Poulton M.M., Jagers S.C., Linde S., Van Zyl D., Danielson L.J. and Matti S. (2013) State of the world's nonfuel mineral resources: Supply, demand, and socio-institutional fundamentals. Annual Review of Environment and Resources, 38, 345-371.

Rademaker J.H., Kleijn R. and Yang Y. (2013) Recycling as a strategy against rare earth element criticality: a systematic evaluation of the potential yield of $\mathrm{NdFeB}$ magnet recycling. Environmental Science \& Technology, 47, 10129-10136.

Raich M., Müller J. and Abfalter D. (2014) Hybrid analysis of textual data: Grounding managerial decisions on intertwined qualitative and quantitative analysis. Management Decision, 52, 737-754.

Reuters (2011) FACTBOX-Japan budgets $\$ 650 \mathrm{mln}$ for rare earths, resources. 05.01.2011. https://www.reuters.com/article/japan-china-rareearth/factboxjapan-budgets-650-mln-for-rare-earths-resources-idUSTOE70404220110105 [Accessed 20.01.2020].

Reuters (2019a) Exclusive: U.S. Army will fund rare earths plant for weapons development. Business News, 11.12.2019. https://www.reuters.com/article/ us-usa-rareearths-army-exclusive/exclusive-u-s-army-will-fund-rare-earthsplant-for-weapons-development-idUSKBN1YF0HU [Accessed 02.02.2020].

Reuters (2019b) Pentagon in talks with Australia on rare earths plant: official. Business News, 27.08.2019. https://www.reuters.com/article/us-usa-rareearths-australia/pentagon-in-talks-with-australia-on-rare-earths-plantofficial-idUSKCN1VH1UY [Accessed 02.02.2020].

Riley C. (2019) BMW and Jaguar Land Rover won't need China's rare earths for their new electric engines. CNN Business, 05.06.2019. https://edition. cnn.com/2019/06/05/tech/rare-earths-china-bmw-jaguar-land-rover/index. html [Accessed 16.07.2019].

ROMEO (2019) Replacement and Original Magnet Engineering Options. http:// www.romeo-fp7.eu/romeo_consortium.htm [Accessed 16.07.2019].

Roskill (2018) Rare Earths: is Magnet Recycling a Solution? 30.08.2018. https:// roskill.com/news/rare-earths-is-magnet-recycling-a-solution/ [Accessed 26.06.2019].

Scheyder E. (2019) Exclusive: Tesla Expects Global Shortage Of Electric Vehicle Battery Minerals - Sources. Reuters, 03.05.2019 https://www.reuters.com/ article/usa-lithium-electric-tesla-exclusive-int/exclusive-tesla-expects-globalshortage-of-electric-vehicle-battery-minerals-sources-idUSKCN1S81QI [Accessed 03.07.2019].

Schmid M. (2018) „Vielleicht schreiben Sie das jetzt besser nicht mit” Interviews mit Unternehmensexperten bei sensiblen Themenstellungen. ["Maybe you better not write that down now" - Interviews with company experts on sensitive topics]. Pp. 105-120 in: Die Zukunft der Qualitativen Forschung. Herausforderungen für die WirtschaftsGesundheits- und Sozialwissenschaften (Müller J. and Raich M., editors). Hallesche Schriften der Betriebswirtschaftslehre. Springer Gabler Wiesbaden [in German].

Schmid, M. (2019a) Rare earths in the trade dispute between the US and China: a déjà vu. Intereconomics, 54, 378-384.

Schmid M. (2019b) Mitigating supply risks through involvement in rare earth projects: Japan's strategies and what the US can learn. Resources Policy, 63, 101457, doi:10.1016/j.resourpol.2019.101457.

Schmid, M. (2020) Unternehmerische Rohstoffstrategien: Zum Umgang mit kritischen Versorgungssituationen (Corporate Raw Material Strategies: How to deal with critical supply situations). Springer Gabler, Wiesbaden, 317 pp. [in German].

Silberglitt R., Bartis J.T., Chow B.G., An D.L. and Brady K. (2013) Critical Materials. Present Danger to U.S. Rand National Defense Research Institute Rand Corporation. https://www.rand.org/content/dam/rand/pubs/ research_reports/RR100/RR133/RAND_RR133.pdf [Accessed 09.07.2019].

Smith B.J. and Eggert R.G. (2016) Multifaceted material substitution: the case of NdFeB 2010-2015. JOM, 68, 1964-1971.

Stock K. (2018) Why Subaru Is Happy to Be Last in Electric Race. Bloomberg, 05.06.2018. https://www.bloomberg.com/news/articles/2018-06-05/whysubaru-is-happy-to-be-last-in-electric-race [Accessed 09.07.2018].

Styczynski A.B. and Hughes L. (2019) Public policy strategies for nextgeneration vehicle technologies: An overview of leading markets. Environmental Innovation and Societal Transitions, 31, 262-272.

The Japan Times (2019) Toyota Honda and Panasonic Consider Joint Venture to Procure Cobalt for Electric Vehicles. 22.01.2019. https://www.japantimes. co.jp/news/2019/01/22/business/corporate-business/toyota-honda-panasonicconsider-joint-venture-procure-cobalt-electric-vehicles/ [Accessed 16.07.2019]. 
The White House (2017) Executive Order on a Federal Strategy to Ensure Secure and Reliable Supplies of Critical Minerals. EO No. 13817, 20.12.2017. https://www.whitehouse.gov/presidential-actions/presidentialexecutive-order-federal-strategy-ensure-secure-reliable-supplies-criticalminerals/ [Accessed 20.01.2020].

Toyota Tsusho (2015) Toyota Tsusho Inks Rare Earths Contract With Indian State Corporation - Rare Earth Oxides Produced In India To Be Exported To Japan Europe And Americas. Press Room, 10.12.2015. https://www.toyota-tsusho. com/english/press/detail/151210_002928.html [Accessed 16.07.2019].

Tracy S.J. (2010) Qualitative quality: eight "Big-Tent" criteria for excellent qualitative research. Qualitative Inquiry, 16, 837-851.

Tran M., Banister D., Bishop J.D. and McCulloch M.D. (2012) Realizing the electric-vehicle revolution. Nature Climate Change, 2, 328-333.

Tse P.-K. (2011) China's Rare Earth Industry. U.S. Geological Survey Open-File Report 2011-1042 http://pubs.usgs.gov/of/2011/1042/of20111042.pdf [Accessed 08.04.2019].

USGS (2019a) Mineral Commodity Summaries 2019. United States Geological Survey. https://www.usgs.gov/centers/nmic/mineral-commodity-summaries [Accessed 10.07.2019] doi:10.3133/70202434.

USGS (2019b) Rare Earths Statistics and Information. United States Geological Survey. https://www.usgs.gov/centers/nmic/rare-earths-statistics-and-information [Accessed 20.06.2019].

USGS (2019c) Lithium Statistics and Information. United States Geological Survey, https://www.usgs.gov/centers/nmic/lithium-statistics-and-information [Accessed 26.01.2020].

USGS (2019d) Cobalt Statistics and Information. United States Geological Survey, https://www.usgs.gov/centers/nmic/cobalt-statistics-and-information [Accessed 26.01.2020].

Vidal O., Goffé B. and Arndt N. (2013) Metals for a low-carbon society. Nature Geoscience, 6, 894-896.
Volkswagen (2019) Volkswagen plans 22 million electric vehicles in ten years. 12.03.2019. https://www.volkswagenag.com/en/news/2019/03/VW_Group_ JPK_19.html [Accessed 26.06.2019].

White L.V. and Sintov N.D. (2017) You are what you drive: Environmentalist and social innovator symbolism drives electric vehicle adoption intentions. Transportation Research Part A: Policy and Practice, 99, 94-113.

Widmer J.D., Martin R. and Kimiabeigi M. (2015) Electric vehicle traction motors without rare earth magnets. Sustainable Materials and Technologies, 3, 7-13.

Xu G., Yano J. and Sakai S.-I. (2016) Scenario analysis for recovery of rare earth elements from end-of-life vehicles. Journal of Material Cycles and Waste Management, 18, 469-482.

Yang Y., Walton A., Sheridan R., Güth K., Gauß R., Gutfleisch O., Buchert M., Steenari B.-M., Van Gerven T. and Binnemans K. (2017) REE recovery from end-of-life NdFeB permanent magnet scrap: a critical review. Journal of Sustainable Metallurgy, 3, 122-149.

Zelger J. (2000) Twelve steps of GABEK WinRelan. Pp. 205-220 in: GABEK II (R. Buber and J. Zelger, editors). Zur Qualitativen Forschung Studienverlag, Innsbruck-Wien.

Zelger J. and Oberprantacher A. (2002) Processing of verbal data and knowledge representation by GABEK $^{\oplus}$-WinRelan ${ }^{\circ}$. Forum Qualitative Sozialforschung/Forum: Qualitative Social Research, 3, 27.

Zheng S. (2019) China will not rule out using rare earth exports as leverage in trade war with US. South China Morning Post, 29.05.2019. https://www. scmp.com/news/china/diplomacy/article/3012199/china-will-not-rule-outusing-rare-earth-exports-leverage [Accessed 31.05.2019].

Ziemann S., Grunwald A., Schebek L., Müller D.B. and Weil M. (2013) The future of mobility and its critical raw materials. Revue de Métallurgie International Journal of Metallurgy, 110, 47-54. 